\title{
8. A plan nobody hopes they will need New Zealand and climate change migration
}

\begin{abstract}
At the Second Pacific Climate Change conference in Wellington in February 2018, New Zealand's Minister for Pacific Peoples, 'Aupito Tofae Su'a William Sio, said New Zealand must have policies in place to deal with the possibility of climate-induced migration from the Pacific Islands. He described having such a policy in place as being akin to a factory preparing an evacuation plan in case of an earthquake: A vital precaution for something everybody hoped would never be needed. But what would that policy look like, how far forward would planners have to think, what issues are involved and who would be responsible for making sure it was effective? This article examines four key areas of concern that will have to be dealt with if an effective policy on climate change-induced migration is to be developed: Public perceptions, the law, maintaining Island culture and identity and changing the existing media narrative on social change. It identifies three groups of key players in the process: Legislators and legal experts, churches, and journalists.
\end{abstract}

Keywords: churches, climate change, journalism, law, media, migration, New Zealand, policy, social justice, South Pacific

\section{PHILIP CASS \\ Unitec, Auckland}

N MARCH 2018, New Zealand's Royal Society Te Apārangi warned that even if all the country commitments from the 2015 Paris Agreement were met, the latest data showed that by the end of the 21 st century the global climate was likely to be operating at $3^{\circ} \mathrm{C}$ above pre-industrial levels. This is substantially higher than the Paris target of less than $2^{\circ} \mathrm{C}$. The temperature rise will affect billions of people. The president of the Royal Society, Professor Richard Bedford, said:

Here in the South Pacific, we are acutely aware of the risks of climate change and sea level rise to our Pacific Island neighbours and we urge all nations to take immediate action on climate change. (Royal Society, 2018)

According to Professor Hans Joachim Schellnhuber, director of the Potsdam Institute for Climate Impact Research, Asia-Pacific is the most vulnerable region. 
If the current climate change scenario did not improve, Schellnhuber predicted that up to one billion people would be forced to migrate by 2100 (Fernandez, 2017).

At the Second Pacific Climate Change conference in Wellington in February 2018, New Zealand's Minister for Pacific Peoples, 'Aupito Tofae Su'a William Sio, said New Zealand must have policies in place to deal with the possibility of climate-induced migration from the Pacific Islands (Sio, 2018). Sio has campaigned on this issue for some time, but said in an interview after the conference that he was working to get fellow ministers to agree to the idea. Sio said many Pacific islands, especially the Cook Islands, Niue and Tokelau, which constitutionally are part of the realm of New Zealand, may look to this country if their populations had to relocate because climate change made their countries uninhabitable. He said New Zealand had to recognise that migration and resettlement might be necessary and its policies on issues like migration and employment must be sufficiently flexible to deal with the situation. Nobody knows how many people may be involved in that movement, but it is unlikely to involve the kind of apocalyptic numbers mentioned by Schellnhuber.

In this the minister, who is of Samoan origin and one of four Pasifika members of Cabinet in the new Labour-led coalition government, was reiterating long-standing calls for New Zealand to prepare for the possibility of climate change-induced migration from the Pacific. Bedford and Bedford (2010, p. 126) described the possible resettlement of many tens of thousands of people as 'a daunting prospect' and were followed in 2013 by Auckland University of Technology academic Vernon Rive who warned that a failure to plan for the possibility of climate-led migration to New Zealand would have consequences which New Zealand and the Pacific may come to regret. Rive also noted, as has the minister, that

... migration is very much a last resort and that for the most part Pacific people would prefer to continue living in their home countries with dignity and safety. However, if migration was necessary it should be carried out with respect for the resilience of people who are no strangers to reestablishing themselves in new environments in response to changing environmental conditions. (Rive, 2013)

Boncour and Burson (2010, p. 5) have argued for the need to manage climate change migration and to understand the implications for host countries and how to manage the complex process of adaptation to their new environment. More recently, 'Akeli (2018) has described climate-induced migration as a critical issue of concern for the Pacific, especially for communities whose legal and physical existence is threatened. 
Sio said long term planning needed to take into account requirements for infrastructure and the question of whether New Zealand was mentally and psychologically prepared for what could happen. He said New Zealand needed to envision what could happen because talking about the possibility of climate change-induced migration now could help pre-empt problems later on.

How do we act in an emergency we don't want to happen? Every factory has an evacuation plan it doesn't ever want to use. (Cass, 2018a)

McLeod (2010, p. 154) argues that working with the Pacific diaspora in New Zealand will be vital to helping climate change migrants settle. ${ }^{1}$ Evidence shows that Pacific Islanders who have settled in New Zealand tend to support settlers by hosting them, helping them find jobs and adjusting to New Zealand. According to Sio (Cass, 2018a) New Zealand has a responsibility to work with the Island nations and help ensure their views and aspirations are heard at international fora. Sio described Vanuatu and Tuvalu as the canary in the coal mine that would sound the alarm for climate change, saying: 'Remember the canary in the coal mine. When it dies, we are all in danger.' (Cass, 2018b) The Minister visited Tuvalu and Kiribati in 2016 and has since shown videos he made recording the effects of climate change on the islands and their people as part of his education campaign (Sio, 2016a; 2016b).

\section{Public perceptions}

Sio's concerns about preparing New Zealanders mentally and psychologically for climate change-induced migration are reflected in Allwood's (2013) study of the New Zealand public's perception of large scale climate change-induced migration. Allwood found that interviewees generally welcomed the idea of having Pacific island migrants move to New Zealand because they were from countries which New Zealand has historically assisted. However, his findings show that they had quite specific caveats. He found that interviewees were intimidated by the potential number of migrants and how they might segregate themselves from the surrounding community (Allwood, 2013, p. 78).

Interview results showed that people thought relocating whole communities to one place would not be welcomed. Participants worried that migrants would not want to integrate and thus isolate themselves from New Zealand communities. They felt there was limited knowledge and understanding of the backgrounds of the migrants coming from the Pacific Islands. They regarded existing New Zealand cultural groups as dominant and expected migrant groups to be subordinate. Participants wanted large scale migration, but not if it changed their way of life (Allwood, 2013, p. 59). The study showed people were concerned that trying to accommodate thousands of people who could possibly be unskilled may create a financial burden for the New Zealand economy. If migrants had job skills and 
some finances to rely on they would be able to contribute to the New Zealand economy (Allwood, 2013, p. 61). ${ }^{2}$

Allwood's findings can be compared with a more recent survey of attitudes towards migration in general which showed that while New Zealanders were generally positive about migrants, 53 percent felt they were putting pressure on public services and 54 percent did not want an increase in immigration numbers (Ipsos, 2016). They are also consistent with surveys in other countries on accommodating refugees. According to a report by Chatham House (2017), recent research showed that around the world there was generalised support for the idea of taking in refugees as a humanitarian duty, but this was counterbalanced by fears of a loss of belonging and identity caused by an influx of refugees. In countries which had suffered terrorist attacks there were security concerns as well as fears of loss of jobs and the effect on public transport and health systems (Chatham House, 2017).

\section{Who will be responsible?}

Who, then, will be responsible for preparing New Zealand for the possibility of climate change-induced migration? I would suggest that three groups will have a vital role to play. Firstly, legislators and legal experts must work to create a legal framework within which such migration can take place. Churches, which are central to Islander identity and culture, have been identified as playing a vital role. The media in New Zealand and the Pacific will have a major role in preparing the public for climate change migration, albeit in a way that may require the New Zealand media to adopt a developmental function and operate as a conduit for the necessary social change.

\section{Legislators and legal experts}

Much of the responsibility for preparing for the possibility of climate-induced change will, inevitably, fall on legislators and legal experts. Bedford and Bedford (2010, p. 94) have argued that amendments to existing immigration laws are likely to be more successful than waiting until a crisis is reached before taking action. Establishing a legal framework to assist those Island populations which want to re-establish their communities in New Zealand will require a major effort on the part of local and international legislators. 'Akeli (2018) suggests focussing on providing a bridge for migration through visas as a way of offsetting the stresses that affect the most vulnerable people, such as children and the elderly, during sudden or forced migration. The two migration schemes which could be most readily adapted appear to be the Recognised Seasonal Employer Scheme and the Pacific Access Category Resident Visa. ${ }^{3}$

Under the Recognised Seasonal Employer (RSE) scheme the horticulture and viticulture industries may recruit workers from overseas for seasonal work 
when there are not enough New Zealand workers. In 2017, 11,000 RSE workers were employed in New Zealand, more than double the number allowed when the scheme started in 2007. Countries whose citizens are eligible for the RSE scheme are Fiji, Kiribati, Nauru, Papua New Guinea, Samoa, Solomon Islands, Tonga, Tuvalu and Vanuatu (Immigration New Zealand a). A limited number of citizens from a handful of island states can apply for a Pacific Access Category Resident Visa. This is essentially a lottery, with citizens of island states aged between 18-45 applying to be registered for a ballot. The visa is indefinite and gives winners the right to work, study and live in New Zealand. The current limits are 75 i-Kiribati, 75 Tuvaluans, 250 Tongans and 250 Fijians. (Immigration New Zealand b)

There is currently no legal framework under which people can claim refugee status in New Zealand because of climate change. There have been two high profile cases in which Islanders have sought leave to stay in New Zealand on the grounds of climate change, but these were dismissed, in one case after several appeals. However, the courts have allowed people to stay on other grounds where there is a family connection. Ioane Teitiota unsuccessfully appealed a decision of the Immigration tribunal on the grounds of climate change in Kiribati (Scoop, 2015).

A family from Tuvalu was allowed to stay on humanitarian grounds at the discretion of the court, which

... accepted that 'exposure to the impacts of natural disasters can, in general terms, be a humanitarian circumstance', that under certain circumstances could make it unjust or unduly harsh to deport a particular individual. It recognised that Tuvalu was particularly vulnerable to the adverse impacts of climate change and environmental degradation, including 'coastal erosion, flooding and inundation, increasing salinity of fresh ground-water supplies, destruction of primary sources of subsistence, and destruction of personal and community property'. (McAdam, 2013; Scoop, 2017)

At the time of the Tuvalu family case, New Zealand's Ministry of Foreign Affairs and Trade said clearly that it did not have an explicit policy to accept people from Pacific island countries due to climate change (Rive, 2013). On a global scale there is in fact debate about whether it would be feasible or even wise to have climate change recognised as a basis for claiming asylum. Some action on developing a legal response to climate change has come from the Nansen Initiative, a Scandinavian project which has carried out consultations in a number of regions, including the Pacific. The Nansen Initiative notes:

Every year around the world, millions of people are forcibly displaced by floods, wind-storms, earthquakes, droughts and other disasters. In the context of climate change, such movements are likely to increase. National 
and international responses to this challenge are insufficient and protection for affected people remains inadequate ... (A) serious legal gap exists with regard to cross-border movements in the context of disasters and the effects of climate change. (The Challenge, n.d.)

Providing a legal framework that protects the status of climate change refugees will also be important, as will defining and protecting the statehood of the migrants. It is clear that those Pacific Islanders considering migration see it in the light of continuing and recreating their societies and cultures in a new home, not abandoning or losing them. Where Island states physically disappear or are otherwise rendered totally uninhabitable, questions will inevitably arise about the continued legal existence of those polities. Given China's illegal creation of a military base on the Spratley reefs in the Philippines Sea, it is not too far-fetched to ask what would happen if it or another naval power anchored an aircraft carrier battle group over a submerged island and declared it was now theirs. Even below the strategic level there are very real considerations about the legal status of refugees. Would they continue to be Tongans, Samoans, i-Kiribati or New Zealanders, or both? Would migrants lose their right to have their citizenship recognised if they were no longer able to live in that country? Burson (2010, p. 172) argues that potential host countries should enter early on into bilateral agreements with countries from which climate change migrants may come and that climate change migrants must be protected from becoming stateless:

If the international community declares these states to continue to exist in some legal sense, perhaps for purposes of continuing to confer nationality and preserving rights to control and exploit land and marine resources, their populations may lack an effective nationality (de facto statelessness), but will not be de jure stateless. (Burson, 2010, p. 168)

Robie (2017) argues that Australia — and especially New Zealand with its large Pasifika population - need to plan for the possibility of large numbers of climate change-induced migrants. New Zealand should start preparing policies for dealing with such an eventuality as soon as possible.

Barnett and Chamberlain (2010, p. 58) argue that whatever approach is taken, it must help climate change migrants by working with peoples' abilities to explore possibilities to respond to their problems and to re-imagine their possibilities in front of them. They suggest creating a set of policies to provide climate change migrants with choices and by increasing the human, financial and social capital they require to be able to adapt to climate change.

\section{Churches}

Outside of the Parliamentary-legal nexus, churches have taken well-publicised social justice-based stands on climate change and migration, such as Pope 
Francis's 'Don't be afraid!' campaign (Associated Press, 2017) churches have been identified by a number of researchers as institutions that could play an important role in communicating climate change issues and helping during the transition period. As one of the few places where people of all New Zealand's communities come together, they are also one of the few places where a narrative of welcoming migrants and integrating them into the existing community as a moral imperative can be sustained away from the expediency of politics and the restrictions of mainstream media practices. (Winfield \& Zoll, 2017) Church-based communities are recognised as focal points for identity and culture and for preserving and developing those aspects of Island societies in whatever setting the diasporic peoples find themselves. Given their absolute centrality to the lives of so many people, the Christian churches in the Pacific and those in New Zealand will play a vital role in communicating messages about climate change.

Of paramount importance to helping Islander migrants adjust to New Zealand is being able to maintain their culture, language, values and spirituality in the new context. According to McLeod (2010, p. 157.), building churches and communities have been identified as key to maintaining culture, as religion and spirituality are integral to Pacific identity. Churches also provide and encourage a sense of belonging. Chatham House (2017) said churches could play an influential role among people who were concerned about climate change-induced migration, especially when people distrusted politicians or NGOs or thought they were being pushed down a particular path by a social or political elite.

Both Catholic and Protestant faith communities have strong commitments to taking action on climate change and creating a sustainable, equitable and just society. As Howell and Kleinsman (2018) pointed out at the 2018 Wellington climate change conference, Pope Francis's Laudato Si (Pope Francis, 2015 ) and the World Council of Churches' An Economy of Life (Mshana \& Peralta, 2015) share a concern for the future of the planet based on the principles of economic, social and climate justice. Laudato Si calls for multiple approaches to confronting the crisis, arguing that:

We need to realise that the solutions will not emerge from just one way of interpreting and transforming reality ... If we are truly concerned to develop an ecology capable of remedying the damage we have done, no branch of the sciences and no form of wisdom can be left out. (Pope Francis, 2015 )

Both documents see capitalism as a major source of environmental and social degradation, rejecting what they describe as a culture of rampant consumerism, greed and selfishness. They also believe that there is a moral imperative to change to a simpler life. Pope Francis ends Laudato Si with a 'Prayer for the Earth' which contains these lines: 
... protect the world and not prey on it,

that we may sow beauty,

not pollution and destruction.

Touch the hearts

of those who look only for gain

at the expense of the poor and the earth. (Pope Francis, 2015)

How effective or widespread church action on the issue is in the Islands is a matter of debate. Speaking in Wellington, Anglican priest Fr Laiseni Liava'a was critical of what he saw as the inactivity of churches in his native Tonga, arguing that climate change was still a relatively new issue at the local church level (Liava'a, 2018). Fr Liava'a, who worked as the National Climate Change Coordinator of Tonga's Third National Communication Project from 2013 to 2014 , said in a later interview that climate change was still very much managed and communicated as an elite level issue while the majority of the people at the grassroots level were left uninformed (Cass, 2018c). In this he was echoing Jackson's (2010) assertion that climate change was known about and understood by specialists, the educated and those with access to international media, but not by ordinary people.

The head of the Catholic church in the kingdom, Cardinal Soane Patita Mafi, said the church had been active, with Caritas involved in community projects in villages and parishes to mitigate the effects of climate change. Projects included planting trees along shorelines as soil protection and to screen buildings from the wind (Grantham, 2018).

In New Zealand, Gillard and Dyson's research (2012) shows opportunities for churches to act as intermediaries for new arrivals, to support communities and foster identity among the diasporic community. Gillard and Dyson believe their work on i-Kiribati migration to New Zealand to be widely relevant to other diasporic Pacific communities. Their report, which was prepared for the Presbyterian church, demonstrates a desire by interviewees for the church to play a role and a recognition of the importance of communities in the resettlement process.

Global warming and rising sea levels play on the minds of I-Kiribati in New Zealand and at home in Kiribati. I-Kiribati in New Zealand are a vanguard of the Kiribati migration, setting up networks and preparing for others to follow. The reality of the crisis is gaining acceptance at home in Kiribati (Gillard \& Dyson, 2012).

Whether participating in concrete action or in promoting issues surrounding climate change-induced migration to their congregations, the churches are well placed to continue promoting the idea that climate change refugees should be welcomed as a religious, ethical, moral and social justice obligation. 
Church-based media organisations such as the World Association for Christian Communication also have a role to play. Working from what is essentially a developmental or transformative viewpoint, they offer a continuing critique of mainstream western journalism and its reporting on issues such as migration. WACC has always emphasised communication as an integral part of human rights and in its assessment of the coverage of migrants and refugees in Europe it underlines the rights of migrants within the broader media narrative:

For refugees...this means being able to express themselves fully and without restrictions, being adequately and respectfully portrayed by the media and having each individual's personal story acknowledged. This goes far beyond the refugee or migrant label. (Pierigh, 2017)

\section{Journalists}

Journalists writing about climate change regard it as an important, but difficult task. New Zealand climate change journalist Samantha Hayes described her goal as being to help people understand climate change, how it affects them and what actions they can take. However, she acknowledged the difficulties surrounding the story, describing it as 'a scientific slow burn, wrapped in politics and vested interests, surrounded by visions of a fiery apocalypse...Journalism has never had a more important or difficult task' (The Spinoff, 2017).

The difficulties of communicating climate change, dissatisfaction with the media's role, the nature of engagement between scientists and the public have been the subject of numerous conference papers and journal articles. More recently, Walters et al. (2017) have argued that scientists who actively engage with the media to promote information about climate change are regarded by other scientists as deviants. In the face of such difficulties, it could seem impossible to make the public understand the science behind climate change and climate change-induced migration. However, climate change can be a human as well as a scientific story. Hayes' colleague Charlie Mitchell said:

In terms of New Zealand, one of the major climate change issues worldwide is forced migration, and that may become a reality for Kiribati in the coming decades. Over 110,000 people live there, and we're their closest wealthy neighbour. Where else are they going to go? (The Spinoff, 2017)

Hendricks (2017) argues that concentrating on the human angle may be the best way to tell the story in terms people understand, to 'focus on the framing, not the facts'. Corner (2016) argues that reporting on people will change climate change from 'a scientific to a social reality'. The UK Climate Change and Migration Coalition (2012) sees climate-induced migration as an important way to humanise the issue. Other international reports see the media as playing not 
just a humanising role, but one which prompts change and response to the issue. Sakarelli (2017) argues that:

Mass media are important forums for the application of ideas and narratives about climate change to the political and economic status quo, therefore media coverage of social impacts of climate change can assist building awareness and momentum for practical action.

If, as Sio (2018) argues, New Zealand has to be prepared psychologically and mentally for the possibility of climate change-induced migration and of providing a carefully thought out response to people who choose to recreate their communities in New Zealand, the media may be called on to play not just its traditional reporting role, but the kind of function that Sakarelli (2017) describes; producing an educative, developmental narrative that may run for decades as sea levels rise and communities decide whether to migrate. A number of experts have argued that the media will have to adapt different strategies to communicate the story of climate change and climate change migration. Brüggemann (2018) extols the virtues of 'slow journalism,' 'a media that builds community sustainability, resilience and adaptability in the face of the challenges of a time of global climate change'. He describes this as 'constructive' journalism, focussing on solutions and providing information about what is being done about climate change.

The educational role of journalism is already acknowledged (Hutt, 2017), but Jackson (2010) argues that the Pacific media need to do more to make people aware of the issue, to act as informant for the public and to create a healthy space for discussion. She claimed that while the effects of climate change were generally known to specialists, those working in the environment sector through non-government organisations, the private sector, government and academics, this was less true for people who relied on local media for news.

The diasporic media, such as the Auckland-based Tongan news service Kaniva Tonga, can serve as a vital link between New Zealand and the Islands in terms of government policy and people's stories. Research by Cass (2015) and Papoutsaki (2016) has shown that diasporic media provide a bridge between the country of origin and New Zealand and have played a part in influencing elections. Social media, especially Facebook and island-specific chat rooms also play an important part in building bridges between existing diasporic communities and island communities. They could be extremely useful in educating people about climate change and changes in government policy and migration rules.

The Chatham House report was concerned about the role of the media in portraying migration movements and noted the danger of what are now known as 'fake news' stories being circulated by right wing agitators and the polarisation of the debate in the media. (Chatham House, 2017) Similarly, Danilova 
(2016) argued that the media could serve to reinforce the image of migrants as criminals and underline anti-immigrant rhetoric. The Chatham House report (2017) said that people involved in surveys were concerned that the far right was better financed, more technically literate and better at using migration to frighten people in order to gain political power. It also argued that pro-migration campaigners had not been very successful in persuading people who were worried about migration.

How the migration story is told clearly presents challenges. As noted above, this is a profoundly human story which may require the mainstream media to perform very differently or to adapt existing working practices. Nobody would pretend this will be easy. Journalists working on climate change such as Hayes (op cit) are already aware of their role as educators, which is a fundamental function of developmental journalism. However, it is likely that negotiating a change in the behaviour of journalists and media outlets will be resisted by many media workers on the grounds that it violates their principles of neutrality and impartiality. As an example, the World Association for Christian Communication (WACC) recommends that journalists working on climate change adhere to what it calls 'the five core principles of ethical journalism: accuracy, independence, impartiality, humanity and accountability'. (Pierigh, 2017) Some journalists might well consider that humanity and accountability are incompatible with independence and impartiality.

The answer well may lie with journalists of tomorrow who will be reporting on the effects of climate change and may very well also be reporting on the arrival of climate change-induced migrants in countries like New Zealand. WACC recommends working with journalism students 'to ensure that the next generation of media professionals will have developed a sensitivity to the topic of migration'. (Pierigh, 2017) This is already being done through the Pacific Media Centre's Bearing Witness project at Auckland University of Technology, a collaborative venture with the University of the South Pacific's journalism programme, the Pacific Centre for the Environment and Sustainable Development (PaCE-SD) and documentary collective Te Ara Motuhenga (Robie \& Chand, 2017). For students involved with the Bearing Witness project, the human side of the story is very personal. As USP journalism and politics student Vilimaina Naqelevuki put it:

Climate change for me is something personal. It's something that affects my country and the Pacific and the world as well. Climate change for me means loss of life, and loss of loved ones. (Cleaver \& Hutt, 2017)

\section{Conclusion}

While sudden, large scale migration to New Zealand on a European scale is unlikely, these are important issues to keep in mind. If people are to be prepared to take a positive view of the possibility of climate change-induced migration, 
then those negotiating that preparation will have to be mindful of how fear and racism can distort people's perceptions. One only has to see how successive right wing governments in Australia have used xenophobia and the largely bogus threat of terrorism to justify migration polices that have been condemned as 'cruel' and 'shocking' by the UN (Wahlquist \& Doherty, 2017).

One of the issues the media will have to face is how to frame the migration story. Of particular concern will be the use of language and the terms used to describe climate change migrants. Leaders from vulnerable island states have rejected the 'climate refugee' label and instead emphasise the 'resilience' of their peoples. In reality, Pacific Islanders reject the label of 'climate refugee' and prefer to be seen as proactive and resilient peoples, searching for their own regional solutions while campaigning for strict mitigation measures. The UNDP has long recognised 'climate refugee' as problematic, but says other words are equally loaded, saying that 'climate migrant' "carries negative connotations which reduce the implied responsibility of the international community for their welfare (Brown, 2007). Ober and Sakdapolrak (2015) say that leaders of vulnerable island states prefer to emphasise the 'resilience' of their peoples. There has been a marked move in recent years to use the term migrant rather than refugees because of what is seen as the pejorative connotations of helplessness in the latter word. Howell and Kleinsman (2018) argue for the use of the word 'ambassadors':

'Refugees' says come and enjoy our charity and become like us. 'Ambassadors' says we regard you as valued contributors. Your story of loss may awaken our sleepwalking.

Developing and maintaining a policy to prepare New Zealand for the possibility of climate change migration will require the participation of several sectors of society. As demonstrated in this article, the groups under consideration all have potentially intersecting and mutually supportive roles in preparing for trans-Pacific population movements. Legislators and lawyers will have to work together to create paths to facilitate migration. New Zealand legislators could use the existing RSE programme as the basis of a programme worked out in collaboration with Island governments to ensure the steady flow of trained workers who could integrate into the New Zealand economy. Churches will have to work with the government to provide support services, to promote different methods of reporting on climate change and migration and to educate coming generations through schools that welcoming climate change refugees is a moral obligation. News media, whether mainstream organs or diasporic media, will have to re-evaluate how they tell the story by adopting new practices and attitudes. This will not be an easy task and more research and self-reflection 
would be useful. Sio's call for the creation of an emergency plan is the latest in a line of warnings that action needs to be taken. If he can assure the co-operation and co-ordination of the kinds of groups identified here, it may be possible to develop a coherent policy in time.

\section{Notes}

1. Moving to New Zealand will not remove the threat of climate change. Islanders living in New Zealand face the same threat. In Auckland, New Zealand's largest city, Pacific Islanders make up 14.6 percent of the population. Many of them live in areas like Mangere and Manukau, which are likely to be flooded as sea levels rise due to climate change. On top of coastal inundation, Auckland will face the threat of flooding as heavy rain becomes more common (Newshub, 2018; Stuff, 2015; Appleby, 2015). In 2015, the head of Victoria University's School of Geography, Environment and Earth Sciences, Dr James Renwick, warned that without urgent mitigation measures, three metres of sea level rise would become a near-certainty within a century. The report by the Parliamentary Commissioner for the Environment suggests the best way of dealing with coastal flooding is a 'managed retreat' and abandoning affected areas (Parliamentary Commissioner, 2015). 2. Countries facing the possibility of climate change migration are actively working to make their people ready to work and integrate into their new environment. Former President Anote tong of Kiribati told the Australian Broadcasting Corporation his country planned to 'train migrants, to up-skill them, so that they can be worthwhile citizens when we relocate them as a community, not as refugees'(ABC, 2014).

3. Seasonal employment agreements for migrant workers also exist in Australia. Until now recruitment has been annual, but there is a move to have three-year visas granted in Australia. (Cass, 2018d)

\section{References}

ABC. (2014). Pacific Islanders reject 'climate refugee' status, want to 'migrate with dignity', SIDS conference hears. Retrieved from www.abc.net.au/news/2014-09-05/ pacific-islanders-reject-calls-for-27climate-refugee27-status/5723078

'Akeli, S. (2018). Climate-induced migration: Where to from here for Pacific nations? Paper presented to the Second Pacific Climate Change conference, Wellington, 21-23 February 2018.

Allwood, J. (2013) How climate change displaces Pacific Islands settlements and the public's perception of large scale migration. Unpublished masters thesis, Waikato University.

Appleby, L. (2015). Simulation shows 'unavoidable' 3m Auckland sea level rise. Retrieved from www.tvnz.co.nz/one-news/new-zealand/simulation-shows-unavoidable-3m-auckland-sea-level-rise-q02974

Associated Press. (2017). Don't be afraid! Pope starts campaign to promote migrants Retrieved from www.pressherald.com/2017/09/29/pope-launches-campaign-topromote-migrants/

Banda, F. (Ed). (2013). Climate change in Africa: A guidebook for journalists. Paris: UNESCO.

Barnett, J., \& Chamberlain, N. (2010). Migration as climate change adaptation: Implications for the Pacific. In Boncour P. \& Burson B. (Eds.). Climate change and migration: South 
Pacific perspectives (pp. 51-58). Wellington: Institute of Policy studies, Victoria University. Bedford, R., \& Bedford, C. (2010) International migration and climate change: A postCopenhagen perspective on options for Kiribati and Tuvalu. In Boncour P. \& Burson B. (Eds.), Climate change and migration: South Pacific perspectives (pp. 89-135). Wellington, NZ: Institute of Policy Studies, Victoria University.

Boncour, P., \& Burson, B. (2010). Climate change and migration in the South Pacific region: Policy Perspectives. In Boncour P. \& Burson B. (Eds), Climate change and migration: South Pacific perspective (pp. 5-29). Wellington, NZ: Institute of Policy Studies, Victoria University.

Brown, O. (2017). Climate change and forced migration: Observations, projections and implications. UNDP: Human Development Report Office.

Brüggemann, M. (2018). Shifting roles of science journalists covering climate change. In Oxford research encyclopedia of climate science. Oxford, UK: Oxford University Press.

Burson, B. (2010). Protecting the rights of people displaced by climate change: Global issues and regional perspectives. In Boncour P. \& Burson B. (Eds.), Climate change and migration: South Pacific perspective (pp. 159-180), Wellington, NZ: Institute of Policy Studies, Victoria University.

Cass. P. (2016). A foreign flower no more: Tongan diasporic media and the 2014 election. Pacific Journalism Review. 22(1), 93-104. doi:10.24135/pjr.v22i1.14

Cass, P. (2017). Strong Tongan, Pasifika representation in Labour's new cabinet, Kaniva Tonga. Retrieved from http://kanivatonga.nz/2017/10/strong-tongan-pasifika-representation-labours-new-cabinet/

Cass, P. (2018a) Climate change demands plan for emergency we hope won't happen says Sio. Kaniva Tonga. Retrieved from http://kanivatonga.nz/2018/03/climate-changedemands-plan-for-emergency-we-hope-wont-happen-says-sio/

Cass, P. (2018b). Pacific Islands are canary in the coal mine for climate change says Minister. Kaniva Tonga. Retrieved from http://kanivatonga.nz/2018/03/pacific-islandscanary-coal-mine-climate-change-says-minister/

Cass, P. (2018c). Tongan churches not doing enough about climate change, says research. Kaniva Tonga. Retrieved from http://kanivatonga.nz/2018/02/tongan-churches-notenough-climate-change-says-research/

Cass, P. (2018d). Tonga wants three year visas for seasonal workers' programme in Australia. Kaniva Tonga. Retrieved from http://kanivatonga.nz/2018/03/tonga-wantsthree-year-visas-seasonal-workers-programme-australia/

Chand, S. (2017). Newspaper coverage of climate change in Fiji: A content analysis. Pacific Journalism Review, 23(1). 169-185. doi:10.24135/pjr.v23i1.310

Chatham House. (2017). Public perceptions of refugees and migrants: the role of politicians, the media and civil society. Retrieved from www.odi.org/sites/odi.org.uk/files/ project-document/11515.pdf

Cleaver, J., \& Hutt, K. (2017). Pacific student journalists passionate about reporting climate change. Retrieved from http://asiapacificreport.nz/2017/04/25/pacific-studentjournalists-passionate-about-reporting-climate-change/

Corner, A., Lewandowsky, S., Phillips, M. and Roberts, O. (2015) The uncertainty handbook. Bristol, UK: University of Bristol.

Danilova, V. (2016) Media and their role in shaping public attitudes towards migrants. United Nations University. Retrieved from https://ourworld.unu.edu/en/media-andtheir-role-in-shaping-public-attitudes-towards-migrants

Deutsche Welle. (2017) Kiribati: a drowning paradise in the South Pacific [Video documentary]. Retrieved from www.youtube.com $/$ watch? $v=T Z 0 j 6 \mathrm{kr} 4 Z J 0 \& t=365 \mathrm{~s}$ 
Fernandez,H.(2017). Climate changewill forcemassmigration of 1 billion by 2100 . Retrieved from www.eco-business.com/news/climate-change-will-force-mass-migration-of-1-billionby-2100/

Gillard, M., \& Dyson, L. (2012). Kiribati migration to New Zealand: experience, needs and aspirations. Auckland, NZ: Impact Research/Presbyterian Church of Aotearoa New Zealand.

Grantham, J. (2018). Tongan Cardinal's Australian interview. Retrieved from catholicoutlook.org/exclusive-tongan-cardinals-australian-interview/

Hendricks R. (2017). Communicating climate change: Focus on the framing, not just the facts. Retrieved from http://theconversation.com/communicating-climate-changefocus-on-the-framing-not-just-the-facts-73028

Howell, J., \& Kleinsman, J. (2018). A religious and moral perspective on climate change in NZ and the Pacific. A paper presented to the Second Pacific Climate Change conference, Wellington, 21-23 February 2018.

Hutt, K. (2017). Pacific-wide study aims to understand how journalists cover climate change. Retrieved from http://asiapacificreport.nz/2017/05/17/pacific-wide-studyaims-to-understand-how-journalists-cover-climate-change/

Ipsos Public Affairs. (2016). International immigration, refugee and Brexit poll. Retrieved from www.curia.co.nz/wp-content/uploads/2016/10/Ipsos-New-ZealandImmigration-Refugees-and-Brexit-Survey-Report-2016.pdf

Jackson, C. (2010). Staying afloat in paradise: Reporting climate change in the Pacific. Oxford, UK: University of Oxford: Reuters Institute Paper.

Immigration New Zealand (n.d.a). Recognised seasonal employer scheme. Retrieved from www.immigration.govt.nz/about-us/research-and-statistics/research-reports/ recognised-seasonal-employer-rse-scheme

Immigration New Zealand (n.d.b). Pacific access category resident visa. Retrieved from www.immigration.govt.nz/new-zealand-visas/apply-for-a-visa/about-visa/pacificaccess-category-resident-visa

Liava'a, L. (2018). Climate change and churches in Tonga: Factors hampering a unified response. Paper presented to the Second Pacific Climate Change conference, Wellington, 23-23 February 2018.

McAdam, J. (2013). No 'climate refugees' in New Zealand. Retrieved from www.brookings.edu/blogs/planetpolicy/posts/2014/08/13-climate-refugees-new-zealand-mcadam

McLeod, D. (2010). Potential impacts of climate change migration on Pacific families living in New Zealand. In Boncour P. \& Burson B. (Eds.), Climate change and migration: South Pacific perspectives. (pp. 135-157). Wellington, NZ: Institute of Policy Studies, Victoria University.

Mshana, R., \& Peralta. A. (2015). Economy of life: Linking poverty, wealth and ecology. Geneva, Switzerland: World Council of Churches (WCC) Publications.

Newshub. (2018). 137,000 Auckland buildings at risk of flooding - Council. Retrieved from www.newshub.co.nz/home/new-zealand/2018/02/137-000-auckland-buildingsat-risk-of-flooding-council.html

Ober, K. and Sakdapolrak, P. (2015) The links between climate change and migration. China Dialogue. Retrieved from www.chinadialogue.net/article/show/single/en/8381The-links-between-climate-change-and-migration

Papoutsaki, E., Cass, P., \& Matbob, P. (2016). Old and new media in the Pacific Islands: synergies, challenges and potential. Paper presented at the International Association for Media and Communication Research Conference (IAMCR), University of Leicester, United Kingdom. 
Parliamentary Commissioner for the Environment. (2015) Preparing New Zealand for Rising Seas. Wellington: New Zealand Parliament. Retrieved from www.pce.parliament. nz/media/1380/preparing-nz-for-rising-seas-web-small.pdf

Pierigh, F. (2017). Changing the narrative: media representation of refugees and migrants in Europe. World Association for Christian Communication (WACC). Retrieved from www.refugeesreporting.eu/wp-content/uploads/2017/10/Changing the_Narrative_Media_Representation_of_Refugees_and_Migrants_in_Europe.pdf

Pope Francis. (2015). Laudato Si: On care of our common home. w2.vatican.va/content/francesco/en/encyclicals/documents/papa-francesco_20150524 enciclica-laudato-si.html

Rive, V. (2013). Safe harbours, closed borders? New Zealand legal and policy responses to climate displacement in the South Pacific. doi:10.2139/ssrn.2328593

Robie, D. (2017) The insecurity legacy of the Rainbow Warrior affair: A human rights transition from nuclear to climate-change refugees. Pacific Dynamics: Journal of Interdisciplinary Research. 1:1. http://pacificdynamics.nz

Robie, D., \& Chand, S. (2017). Bearing Witness 2016: A Fiji climate change journalism case study. Pacific Journalism Review, 23(1), 186-205. doi: 10.24135/pjr.v23i1.257

Royal Society of New Zealand. (2018). Royal Society Te Apārangi supports joint statement on climate change by Commonwealth academies of science. Retrieved from https://royalsociety.org.nz/news/royal-society-te-aparangi-supports-joint-statementon-climate-change-by-commonwealth-academies-of-science/

Sakarelli, M. (2017). The mediation of climate change induced migration. Implications for meaningful media discourse and empowerment of key intermediaries to raise public awareness. Bristol, UK: University of Bristol.

Scoop. (2015). Teitiota climate change/refugee case: Application dismissed. Retrieved from www.scoop.co.nz/stories/PO1507/S00182/teitao-climate-changerefugee-caseapplication-dismissed.htm

Sio, W. (2018). Climate change observations in the Pacific. Paper presented to the Second Pacific Climate Change conference, Wellington, 21-23 February 2018.

Sio, W. (2016). Kiribati video. www.youtube.com/watch?v=uDG7A0-UEb4

Sio, W. (2016). Tuvalu video. www.youtube.com/watch?v=ZEtCQVcYKbc

The challenge (n.d.). The Nansen Initiative: Disaster-induced cross-border displacement. Retrieved from www.nanseninitiative.org/global-consultations/

The Spinoff. (2017). Covering climate change: journalism's biggest and most difficult story, ever. Retrieved from http://thespinoff.co.nz/science/climate-changeweek/16-08-2017/covering-climate-change-journalisms-biggest-and-most-difficultstory-ever/

Stuff. (2017). Sea level rise could swamp some New Zealand cities, Stuff. Retrieved from www.stuff.co.nz/environment/climate-news/90657833/sea-level-rise-could-swampsome-new-zealand-cities

UK Climate Change and Migration Coalition. (2012) Communicating climate change and migration. London, UK: UKCCMC.

Wahlquist, C., \& Doherty, B. (2017). UN condemns Australia on Indigenous detentions and asylum policies. Retrieved from www.theguardian.com/australia-news/2017/ oct/20/un-condemns-australia-on-indigenous-detentions-and-asylum-policies

Walters, S., de Silva-Schmidt, F., \& Brüggemann, M. (2017). Knowledge brokers to opinion makers: How physical presence affected scientists' Twitter use during the COP21 climate change conference. International Journal of Communication, 11, 570-591. 
Winfield, N., \& Zoll, R. (2017). Pope launches campaign to promote migrants. Retrieved from www.pressherald.com/2017/09/29/pope-launches-campaign-to-promote-migrants/ Winnard D., Lee M., \& Macleod, G. (2015). Demographic profile: 2013 census, population of Counties Manukau. Auckland, NZ: Counties Manukau Health.

Dr Philip Cass is senior lecturer in the Master in International Communication programme at Unitec, Auckland, and associate editor of Pacific Journalism Review. He attended the Second Pacific Climate Change conference in Wellington on behalf of the Auckland Catholic Justice and Peace Commission. He would like to acknowledge the contributions of Dr KaSing Yeung and Dr Maya Bernardo to this article.

cass.philip@gmail.com

\section{PACIFIC MEDIA CENTRE}

The Pacific Media Centre (Te Amokura) focuses on Mãori, Pacific and diversity media and community development. It's the only media research and community resource centre of its kind in Aotearoa/New Zealand.

Pacific Media Centre activities include:

- International book and research publication

- Publication of the peer-reviewed Pacific Journalism Review research journal and Pacific Journalism Monographs

- Publication of Pacific Media Centre Online as a media resource and postgraduate outlet

- Publication of Pacific Media Watch, a regional media monitoring service

- Journalism and media research opportunities

- Asia-Pacific internships for postgraduate students 